\title{
Effect of Caffeine on Some Transferase Enzymes Activities
}

\author{
Zyad Hussein J.Al-Qaisi \\ Department of Chemistry, College of Science, Al-Mustansiryh University \\ PO box 46010, Baghdad, Iraq \\ Tel: 964-790-197-7781_E-mail: zyadalqaisi@yahoo.com \\ Selma Abdul Rudha Abbass \\ Department of Chemistry, College of Science, Al-Mustansiryh University \\ Baghdad, Iraq \\ Tel: 964-770-062-5383 E-mail: dr.salma_ar@yahoo.com \\ Amer Hasan Abdullah \\ Department of Chemistry, College of Science, Al-Mustansiryh University \\ PO box 46155, Baghdad, Iraq
}

Tel: 964-790-390-5863 E-mail: Aammr1965@yahoo.com

Received: June 17, 2010 Accepted: July 6, 2010 doi:10.5539/ijc.v3n2p140

\begin{abstract}
This study was designed to show the effects of caffeine on the activities of aspartate aminotransferase (AST), alanine amino transferase (ALT), gama glutamate transferase ( $\gamma$-GT) enzymes in the sera. Caffeine demonstrated activation on (AST) and (ALT) activities, inhibitory effects on the ( $\gamma$-GT) activity, and these effects increased with increasing the concentration of the compound. Kinetic properties of (AST) and (ALT) activities revealed (by caffeine) non-competitive type of activation, and of ( $\gamma$-GT) activity competitive inhibitors
\end{abstract}

Keywords: GOT, GPT, GGT

\section{Introduction}

Caffeine is a natural compound that is made by plants. Caffeine is classified as a methyl xanthine alkaloid. Molecular structure of Caffeine has:<smiles>CN1C(=O)C2C(N=CN2C)N(C)C1=O</smiles>

At present there are 63 different species of plants known to contain caffeine, the most common food sources of caffeine in the human diet have been coffee (from the coffee plant), tea (from the tea plant), and chocolate (from the cacao plant) [Koppelstaetter, 2005].

Caffeine from coffee or other beverages is easily absorbed by the stomach and small intestine within 45 minutes of ingestion, and it is rapidly distributed throughout all tissues of the body [Liguori A, 1997]. Caffeine is metabolized in the liver, through demethylation and oxidation, it forms three dimethylxanthines, and each of these metabolites is further metabolized and then excreted in the urine [Fisone, 2004].

Caffeine causes an increase in blood flow to the kidneys and an increase in the production of urine. It also decreases the tubular reabsorption of sodium and water, resulting in more dilute urine [Fredholm, 1999] 
Caffeine stimulates skeletal muscle by increasing the strength of contraction and decreasing fatigue. It also stimulates the breakdown of glycogen and lipids to enhance endurance [Latini S, 2001; Addicot MA, 2009].

In view of the importance of transferase enzymes reactions like Glutamate Oxaloacetate Transaminase (GOT), Glutamate Pyruvate Transaminase (GPT) and Gama Glutamate Transferase (GGT) which form links between the metabolism of amino acids, carbohydrates and fats

\subsection{Glutamate Oxaloacetate Transaminase (GOT) activity (EC 2.6.1.1)}

It's called also aspartate aminotransferase (AST), is one of the most important of transaminases enzyme, and catalyzes the transfer of the amino group of aspartate to $\alpha$-ketoglutrate. GOT is widely distributed in human tissues; heart, liver, skeletal muscle and kidney. The optimum conditions of maximum enzyme activity are $\mathrm{pH}=7.4$, temp. $=37 \mathrm{c}^{\circ}$. The enzyme stability 3 days in $25 \mathrm{c}^{\mathrm{o}}, 1$ week in $5 \mathrm{c}^{\mathrm{o}}$ and 1 month in $-25 \mathrm{c}^{\mathrm{o}}$. The clinical usefulness of the enzyme is largely restricted to the diagnosis of heart and liver diseases. Large amount of GOT may be released into the blood. Very high levels are observed in acute liver disease while lesser elevation is seen in chronic liver disease [L.Stryer, 1988; Robert, 1997; Joan F., 1988].

\subsection{Glutamate Pyruvate Transaminase (GPT) activity (EC 2.6.1.2)}

It's also called alanine amino transferase (ALT) which is prevalent in mammalian tissue catalyzes the transfer of the amino group of alanine to $\alpha$-ketoglutrate.GPT found in a highest concentration in liver in spite of its active occurrence in skeletal muscles, heart and kidney. The GPT activity in tissues is generally less than GOT. Significant elevation of S.GOT occurs in sever acute hepatitis where the enzyme is released in to the circulation. GPT level is found to increased in the following diseases; infection hepatitis, liver cirrhosis and biliary cirrhosis, obstructive jaundice, liver cancer [Joan F., 1988; Thommas M., 1982; Ottaway G.H., 1984; Harry R.Mathews, 1997].

\subsection{Gama Glutamate Transferase ( $\gamma-G T)$ activity (EC 2.3.2.2)}

It's also called Gama Glutamate Transpeptidase ( $\gamma$-GT) or (GGT) is found in kidneys and liver and catalyzes the transfer of a gamma-glutamyl group from glutathione (GSH)to an amino acid. GGT levels are increased in most forms of liver disease, especially cholestasis, a plasma membrane-bound enzyme, provides the only activity capable to effect the hydrolysis of extracellular glutathione, thus favoring the cellular utilization of its constituent amino acids [Elsevier, 1997].

\section{Aim of study}

Peoples in the world consume large quantities of caffeine through having main sources of caffeine in general life which are: coffee, tea, chocolate etc, therefore This study was designed to show the effects of caffeine on some transferases enzymes such as GOT,GPT and $\gamma$-GT.

\section{Materials and methods}

\subsection{Effect of caffeine on GOT and GPT activities}

Colorimetric determination of GOT or GPT activity according to the following reactions:

L-Aspartate $+\alpha$-ketoglutrate

Alanine $+\alpha$-ketoglutrate

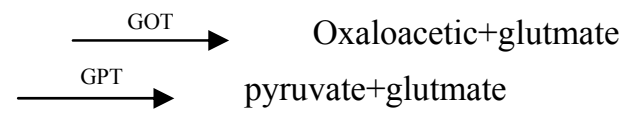

The pyruvate or oxaloacetat formed was measured in its derivated form 2,4-dinitrophenylhydraone, which was absorbed at wave length $505 \mathrm{~nm}$ [Reitman, 1957; Cabaud, 1956; Karmen, 1955].

\subsection{Effect of caffeine on $\gamma$-GT activity}

Kinetic colorimetric method for the determination of $\gamma$-GT activity was assayed by Persijn and Van Der Slik [Persijn, 1976; Z.Klin, 1974]. The principle of the method was the measurement of the 5-amino-2-nitro-benzoate form from reaction, which was absorbed at wave length $405 \mathrm{~nm}$.

L- $\gamma$-gluamyl-3-carboxy-4-nitroanilide+glycylglycine $\underset{- \text {-GT }}{\longrightarrow}$ L- $\gamma$-glutamyl-glycylglycine +5 -amino-2-nitro-benzoate

3.2.1 A stock solution $(0.1 \mathrm{M})$ of caffeine was prepared and the following concentration of $\left(1 \times 10^{-2}, 1 \times 10^{-3}, 1 \times 10^{-4}, 1 \times 10^{-5}, 1 \times 10^{-6}, 1 \times 10^{-7}, 1 \times 10^{-8}\right) \mathrm{M}$ were prepared by diluting with distilled water.

The enzymes GOT, GPT and $\gamma$-GT activities were measured in human serum by using the same methods of these enzymes with replace $100 \mu 1$ of buffer with $100 \mu$ l of caffeine.

The inhibition percentage was calculated by comparing the activity with and without the caffeine and under the same conditions, according to the equation 
The activity in the presence of inhibitor

$\%$ Inhibition $=100-100 \mathrm{x}$

The activity in the absence of inhibitor

The activation percentage was calculated by comparing the activity with and without the activator and under the same conditions, according to the equation

The activity in the presence of activator

$\%$ Activation $=100 \mathrm{x}$

The activity in the absence of activator

3.2.2 A constant concentration of caffeine $\left(1 \times 10^{-1}\right.$ and $\left.1 \times 10^{-8}\right) \mathrm{M}$ were used with different substrate concentrations of $(40,80,120,160,200) \mathrm{mmol} / \mathrm{L}$ for GOT,GPT and $(0.4,0.8,1.2,1.62) \mathrm{mmol} / \mathrm{L}$ for $\gamma$-GT, to study the type of inhibition or activation. Buffers were used to prepare different substrates concentrations of these enzymes, GOT, GPT (phosphate buffer pH 7.4, $100 \mathrm{mmol} / \mathrm{L}$ ) and $\gamma$-GT (TRIS buffer pH 8.25, $100 \mathrm{mmol} / \mathrm{L}$ )

The enzymes activiteis were determined with and without caffeine, by using the Lineweaver-Burk equation and plotting 1/v against 1/[s] were evaluated values [Linweaver, 1934]:

a) ki, b) Apparent $v_{\max }\left(v_{\text {mapp }}\right)$, c) Apperent $k_{m}\left(k_{\text {mapp }}\right)$, d) Type of inhibition or activation.

\section{Results and discussion}

This research addresses investigation of the effects of caffeine of GOT, GPT and $\gamma$-GT enzymes. The biochemical tests revealed that caffeine caused inhibitory effects on $\gamma$-GT enzyme activity, and activatory effects on GOT and GPT enzymes activities. Figure (1).

The normal value of the GOT enzyme activity was $(77 \mathrm{U} / \mathrm{L})$. The relationship between caffeine concentration versus and the activity of enzyme as shown in figure (2).these results observed that any increase in compound concentrations caused increase in percentage of activation of enzyme. The greater activation of caffeine was demonstrated at concentration $(0.1 \mathrm{M})(20.78 \%)$ as shown in figure $(3)$.

The normal value of the GPT enzyme activity was $(55 \mathrm{U} / \mathrm{L})$. The relationship between caffeine concentration versus and the activity of enzyme as shown in figure (4).these results observed that any increase in compound concentrations caused increase percentage of activation of enzyme. The greater activation of caffeine was demonstrated at concentration $(0.1 \mathrm{M})(22.72 \%)$ as shown in figure $(5)$.

The normal value of the $\gamma$-GT enzyme activity was $(26.18 \mathrm{U} / \mathrm{L})$. The relationship between caffeine concentration versus and the activity of enzyme as shown in figure (6).these results observed that any increase in compound concentrations caused increase in percentage of inhibition of enzyme. The greater inhibition of caffeine was demonstrated at concentration $(0.1 \mathrm{M})(55 \%)$ as shown in figure $(7)$.

Competitive, noncompetitive and uncompetitive inhibition can be easily distinguished with the use of double reciprocal plot of the Lineweaver-Burk plot. Two sets of rate determination in which enzyme concentration was held constant, were carried out. In the first experiment the velocity of enzyme without inhibitor was established, in the second experimental constant amount of inhibitor is included in each enzyme assay. Varieties of substances have the ability to reduce or eliminate the catalytic activity of specific enzyme [U.Satyanarayna, 2003].

Table (2) and figure (8) showed that the type of enzyme activation using Lineweaver-Burk plot for caffeine on serum GOT activity. The $\mathrm{V}_{\max }$ and $\mathrm{K}_{\mathrm{m}}$ with $\left(10^{-1}\right.$ and $\left.10^{-8}\right) \mathrm{M}$ of caffeine and without it, $\mathrm{V}_{\max }$ and $\mathrm{K}_{\mathrm{m}}$ without caffeine was $67 \mathrm{U} / \mathrm{L}, 200 \mathrm{M}$ respectively. A liquate $10^{-1}$ and $10^{-8} \mathrm{M}$ of caffeine were non-competitive activation for enzyme activity. Non-competitive activation changed the $\mathrm{V}_{\max }$ of the enzyme but not the $\mathrm{K}_{\mathrm{m}}$. When concentration of caffeine $\left(10^{-1}, 10^{-8}\right) \mathrm{M}$ the $\mathrm{V}_{\max }$ were $(200,100) \mathrm{U} / \mathrm{L}$ respectively. By using Lineweaver-Burk equation was calculated the $\mathrm{Ki}$ values of enzyme for compound which was studied in different concentration. The Ki of caffeine in $\left(10^{-1}, 10^{-8}\right) \mathrm{M}$ were $\left(0.15,3 \times 10^{-8}\right) \mathrm{M}$ respectively

Table (2) and figure (9) showed that the type of enzyme activation using Lineweaver-Burk plot for caffeine on serum GPT activity. The $\mathrm{V}_{\max }$ and $\mathrm{K}_{\mathrm{m}}$ with $\left(10^{-1}\right.$ and $\left.10^{-8}\right) \mathrm{M}$ of caffeine and without it, $\mathrm{V}_{\max }$ and $\mathrm{K}_{\mathrm{m}}$ without caffeine was $100 \mathrm{U} / \mathrm{L}, 400 \mathrm{M}$ respectively. A liquate $10^{-1}$ and $10^{-8} \mathrm{M}$ of caffeine were non-competitive activation for enzyme activity. Non-competitive activation changed the $\mathrm{V}_{\max }$ of the enzyme but not the $\mathrm{K}_{\mathrm{m}}$. When concentration of caffeine $\left(10^{-1}, 10^{-8}\right) \mathrm{M}$ the $\mathrm{V}_{\max }$ were $(250,111,111) \mathrm{U} / \mathrm{L}$ respectively. By using Lineweaver-Burk equation was calculated the Ki values of enzyme for compound which was studied in different concentration. The Ki of caffeine in $\left(10^{-1}, 10^{-8}\right) \mathrm{M}$ were $\left(0.166,1 \times 10^{-7}\right) \mathrm{M}$ respectively. 
The enzymes play important role in amino acid metabolism and in the urea and tricarboxylic acid cycles. We suggested that caffeine molecule has $(\mathrm{N}-$ and $\mathrm{O}=$ ) groups by which, it activates the active sides of amino acids of GOT and GPT enzymes by increasing affinity of active sides of enzymes to react with the substrates. The results of our study is in agreement with before studies of same enzymes [Springer Berlin, 2004].

Table (2) and figure (10) showed that the type of enzyme inhibitor using Lineweaver-Burk plot for caffeine on serum $\gamma$-GT activity. The $\mathrm{V}_{\max }$ and $\mathrm{K}_{\mathrm{m}}$ with $\left(10^{-1}\right.$ and $\left.10^{-8}\right) \mathrm{M}$ of caffeine and without it, $\mathrm{V}_{\max }$ and $\mathrm{K}_{\mathrm{m}}$ without caffeine was $37.037 \mathrm{U} / \mathrm{L}, 0.40 \mathrm{M}$ respectively. A liquate $10^{-1}$ and $10^{-8} \mathrm{M}$ of caffeine were competitive inhibtion for enzyme activity. Competitive inhibition changed the $\mathrm{K}_{\mathrm{m}}$ of the enzyme but not the $\mathrm{V}_{\max }$. When concentration of caffeine $\left(10^{-1,} 10^{-8}\right) \mathrm{M}$ the $\mathrm{K}_{\mathrm{m}}$ were $(1.429,0.714) \mathrm{M}$ respectively. By using Lineweaver-Burk equation was calculated the $\mathrm{Ki}$ values of enzyme for compound which was studied in different concentration. The Ki of caffeine in $\left(10^{-1}, 10^{-8}\right) \mathrm{M}$ were $\left(0.0388,1.27 \times 10^{-8}\right) \mathrm{M}$ respectively.

Molecular of caffeine inter action between the groups $(\mathrm{N}-$ and $\mathrm{O}=)$ with active sides of amino acids of $\gamma$-GT enzyme. The results of our study are in agreement with before studies of same enzyme [Burg, 2002].

The tripeptide glutathione (GSH) is used by cells to detoxify hydroperoxides, produced during oxidative stress, and is consumed in the process. Previous studies have indicated that cells can be protected against oxidative stress by extracellular GSH through its degradation catalyzed by the exoenzyme gamma-glutamyl transpeptidase (GGT) and its de novo synthesis within the cytosol. [A Kugelman, 1994] Because of this, induction of GSH depletion has been proposed as a good strategy for sensitizing tumor cells to anti tumor agents [Castro, 2002].

We hypothesized that (GGT) would be increased as part of the adaptation of cells to oxidative stress.

\section{References}

A Kugelman, HA Choy, R Liu, MM Shi, E Gozal and HJ Forman. (1994). Gamma-Glutamyl transpeptidase is increased by oxidative stress in rat alveolar L2 epithelial cells, Am. J. Respir. Cell Mol. Biol., Vol 11, No. 5, 11, 586-592.

Addicot MA, Yang LL, Peiffer AM, Burnett LR. (2009). The effect of daily caffeine use on cerebral blood flow, Hum Brain Map, 30(10):3102-14.

Burg, D., Filippov, D.V., Hermanns, R., van der Marel, G.A., van Boom, J.H.; Mulder, G.J. (2002). Bioorganic \& Medicinal Chemistry, Volume 10, Number 1, p.195-205.

Cabaud et al. (1956). Am.J.Clin.Path., 1956, 26, 1101

Castro, B, Alonso Varona, A, del Olmo, M, Bilbao, P, Palomares, T. (2002). Role of gamma-glutamyltranspeptidase on the response of poorly and moderately differentiated rhabdomyosarcoma cell lines to buthionine sulfoximine-induced inhibition of glutathione synthesis. Anticancer-Drugs. 2002 Mar; 13(3): 281-91.

Elsevier Science Inc. (1997). Free radical biology and medicine, volume 22, issue 5, pp 853-860.

Fisone, G. Borgkvist, A. Usiello,A. (2004). Caffeine as a psychomtor stimulant:mechanism of action. Cell Mol Life Sci, 61(7-8):857-72.

Fredholm, B. B., K. Bättig, J. Holmén, A. Nehlig, and E. E. Zvartau. (1999). Actions of caffeine in the brain with special reference to factors that contribute to its widespread use. Pharmacological Reviews, 51 (1): 83-133.

Harry R.Mathews, Richard A. Preed, Roger L. Miesfeld. (1997). Biochemistry a short course, Wiley-Liss, U.S.A, p255.

Joan F., Zilva, Peter R. Pannall and Philip D. Mayne. (1988). Clinical chemistry in Diagnosis and Treatment, $5^{\text {th }}$ ed, p523.

Karmen A. (1955). J.Clin. Invest. 34, 131.

Koppelstaetter, F., C. Siedentopf, T. Poeppel, I. Haala, A. Ischebeck, F. Mottaghy, et. al. (2005). Influence of Caffeine Excess on Activation Patterns in Verbal Working Memory. Presentation on December 1, 2005 at the conference.

L. Stryer. (1988). Biochemistry, $3^{\text {rd }}$ ed W.H.,Freeman and company, New york, p 596.

Latini S,Pedata F. (2001). Adenosine in the central nervous system:release mechanism and extracellular concentrations. J.Neurochem, 79 (3):463-84. 
Liguori A, Hughes JR, Grass JA. (1997). Absorption and subjective effects of caffeine from coffee cola and capsules, Pharmacal Biochem Behav, 58(3):721-6. doi:10.1016/50091-3057(97)00003-8, http://dx.doi.org/10.1016/50091-3057(97)00003-8.

Linweaver, H. Burke, D. (1934). J.Am.chem.Soc. The Determintion of enzyme Dissociation constants. 56, 658.

Ottaway G.H., Apps D.K., Bailliere T. (1984). Biochemistry, $4^{\text {th }}$ ed London, p322.

Persijn, Van Der Silk. (1976). J.Chem.Clin.Biochem. A new method for the Determination of Gamma-glutamyl transferase.4,4 21 .

Reitman, S. Frankel, S. (1957). Am.J.Clin.path. A colorimetric method for the determination of serum glutamic oxalacetic and glutamic pyruvic transaminases.28, 56.

Robert L.Katherine J.Joseph J. (1997). Principles and Applications of Inorganic, Organic and Biological Chemistry, $2^{\text {nd }}$ ed., WCB, MC.Graw Hill, p 242.

Springer Berlin, Heidelberg. (2004). Effect of some -SH and other reagents on aspartate aminotransferase and L -alanine aminotransferase of Paramphistomum explanatum fischoeder. Biomidical and life sciences, Saturday, December 11, 2004.

Thommas M., Derlin J. (1982). Text of Biochemistry with Clinical Correlations. Awiley Medical publication, New york, p185.

U.Satyanarayna. (2003). Biochemistry ${ }^{2 n d}$ ed. Books and Allied (P)LTD, India, 2003, pp 91-95.

Z. Klin. (1974). Chem.Klin.Biochem, 12, 228.

Table 1. The effect of different concentrations of caffeine on the activity of GOT,GPT, $\gamma$-GT enzyme in human serum

\begin{tabular}{|l|l|l|l|l|l|l|l|}
\hline Number & Conc.[M] & $\begin{array}{c}\text { GOT activity } \\
\text { U/L }\end{array}$ & $\begin{array}{c}\mathbf{\%} \\
\text { Activation }\end{array}$ & $\begin{array}{c}\text { GPT } \\
\text { activity } \\
\text { U/L }\end{array}$ & $\begin{array}{c}\mathbf{\%} \\
\text { Activation }\end{array}$ & $\begin{array}{c}\boldsymbol{\gamma} \text {-GT activity } \\
\text { U/L }\end{array}$ & $\begin{array}{c}\text { \% } \\
\text { Inhibition }\end{array}$ \\
\hline $\mathbf{1}$ & $\mathbf{0}$ & 77 & 0 & 55 & 0 & 26.18 & 0 \\
\hline $\mathbf{2}$ & $\mathbf{1 0}^{-1}$ & 78 & 20.78 & 56.5 & 22.72 & 11.78 & 55 \\
\hline $\mathbf{3}$ & $\mathbf{1 0}^{-2}$ & 79 & 16.88 & 57 & 14.54 & 13.09 & 50 \\
\hline $\mathbf{4}$ & $\mathbf{1 0}^{-3}$ & 80 & 11.68 & 55.5 & 12.72 & 20.94 & 20 \\
\hline $\mathbf{5}$ & $\mathbf{1 0}^{-4}$ & 81 & 9.09 & 56 & 7.27 & 23.56 & 10 \\
\hline $\mathbf{6}$ & $\mathbf{1 0}^{-5}$ & 84 & 5.19 & 59 & 5.45 & 24.87 & 5 \\
\hline $\mathbf{7}$ & $\mathbf{1 0}^{-\mathbf{6}}$ & 86 & 3.89 & 62 & 3.63 & 25.55 & 2.4 \\
\hline $\mathbf{8}$ & $\mathbf{1 0}^{-\mathbf{7}}$ & 90 & 2.3 & 63 & 2.73 & 26.18 & 0 \\
\hline $\mathbf{9}$ & $\mathbf{1 0}^{-\mathbf{8}}$ & 93 & 1.3 & 67.5 & 1.81 & 26.18 & 0 \\
\hline
\end{tabular}

Table 2. The kinetic propereties of GOT,GPT, $\boldsymbol{\gamma}$-GT with caffeine

\begin{tabular}{|l|l|l|l|l|l|}
\hline Enzymes & $\begin{array}{l}\text { Con.of } \\
\text { caffeine }\end{array}$ & $\mathbf{K}_{\text {map }}(\mathbf{M})$ & $\mathbf{V}$ map U/L & Ki (M) & \multirow{2}{*}{ Type of effection } \\
\hline \multirow{2}{*}{ GOT } & $\mathbf{1 0}^{-1}$ & 200 & 200 & 0.15 & \multirow{2}{*}{ Non-competitive } \\
\cline { 2 - 5 } & $\mathbf{1 0}^{-\mathbf{8}}$ & 200 & 100 & $3 \times 10^{-8}$ & \\
\hline \multirow{2}{*}{ GPT } & $\mathbf{1 0}^{-1}$ & 400 & 250 & 0.1666 & \multirow{2}{*}{ Non-competitive } \\
\cline { 2 - 5 } & $\mathbf{1 0}^{-8}$ & 400 & 111.111 & $1 \times 10^{-7}$ & \\
\hline \multirow{2}{*}{$\boldsymbol{\gamma}$-GT } & $\mathbf{1 0}^{-1}$ & 1.429 & 37.037 & 0.0388 & \multirow{2}{*}{ Competitive } \\
\cline { 2 - 5 } & $\mathbf{1 0}^{-8}$ & 0.714 & 37.037 & $1.27 \times 10^{-8}$ & \\
\hline
\end{tabular}




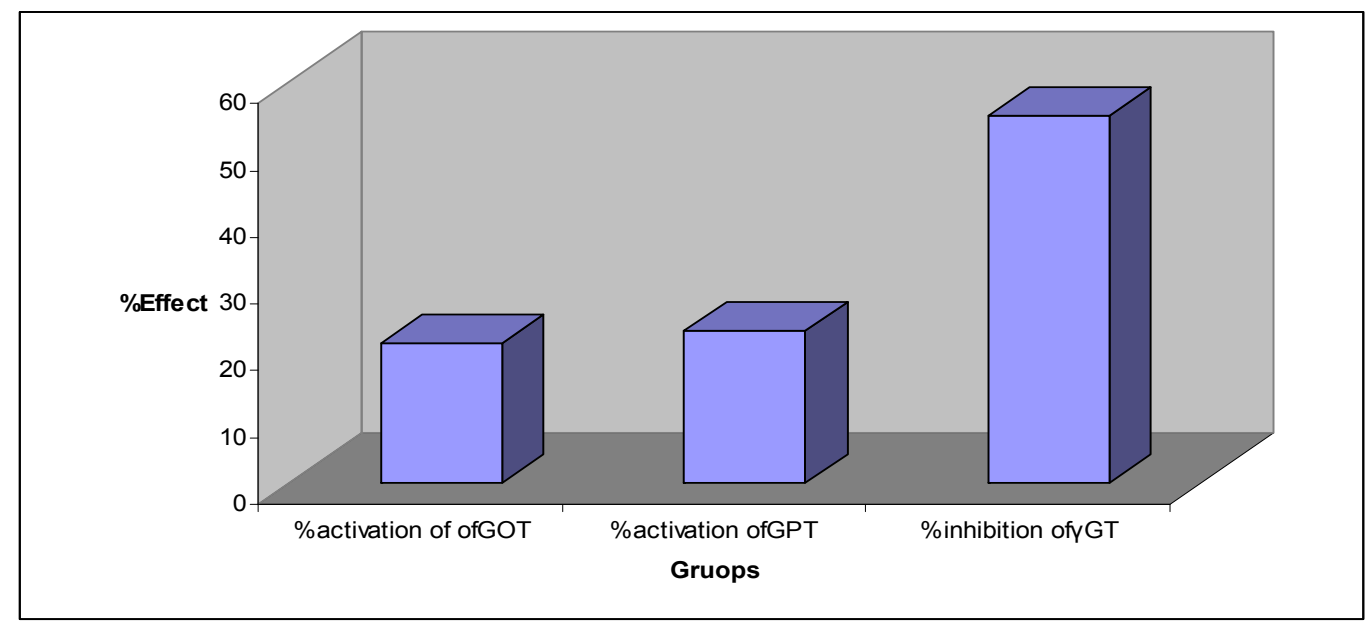

Figure 1. \% Effect of GOT, GPT, $\gamma$-GT enzymes activities with $0.1 \mathrm{M}$ caffeine

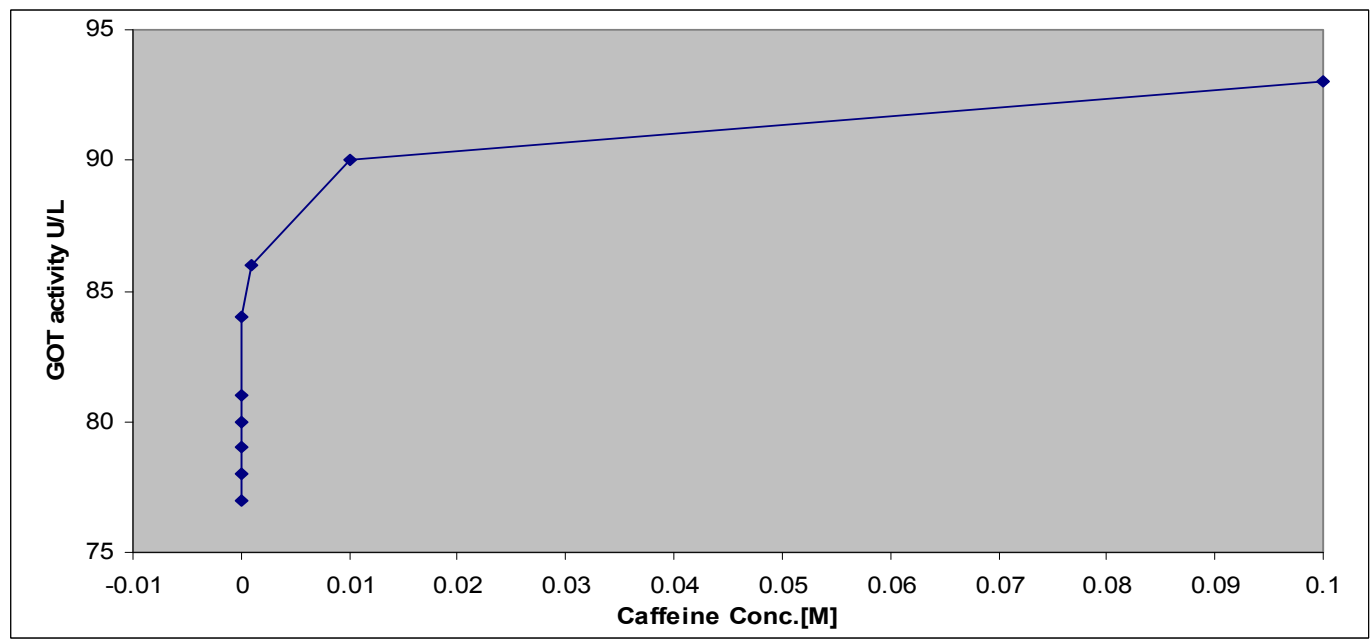

Figure 2. The relationship between concentration of caffeine and GOT enzyme activity

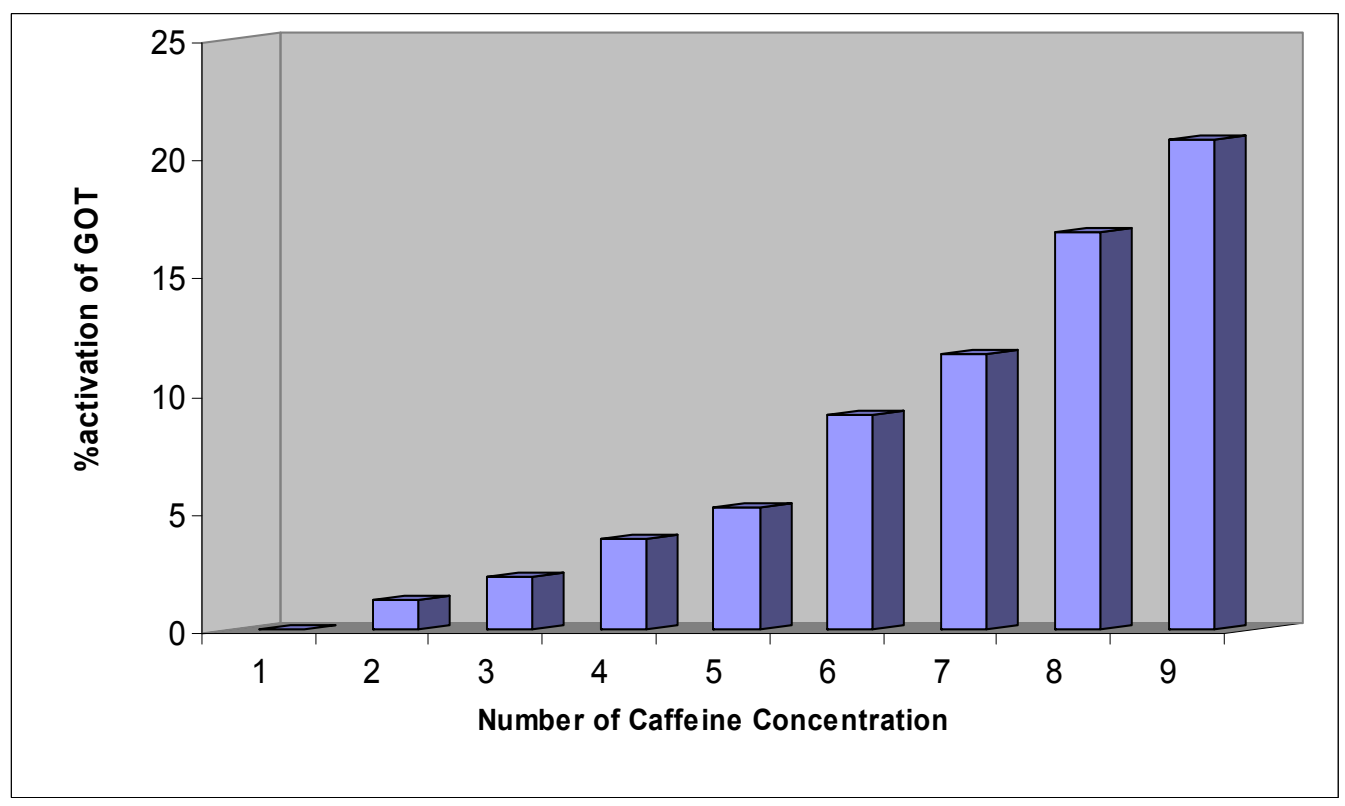

Figure 3. The percentages of activation GOT enzyme and caffeine concentration 


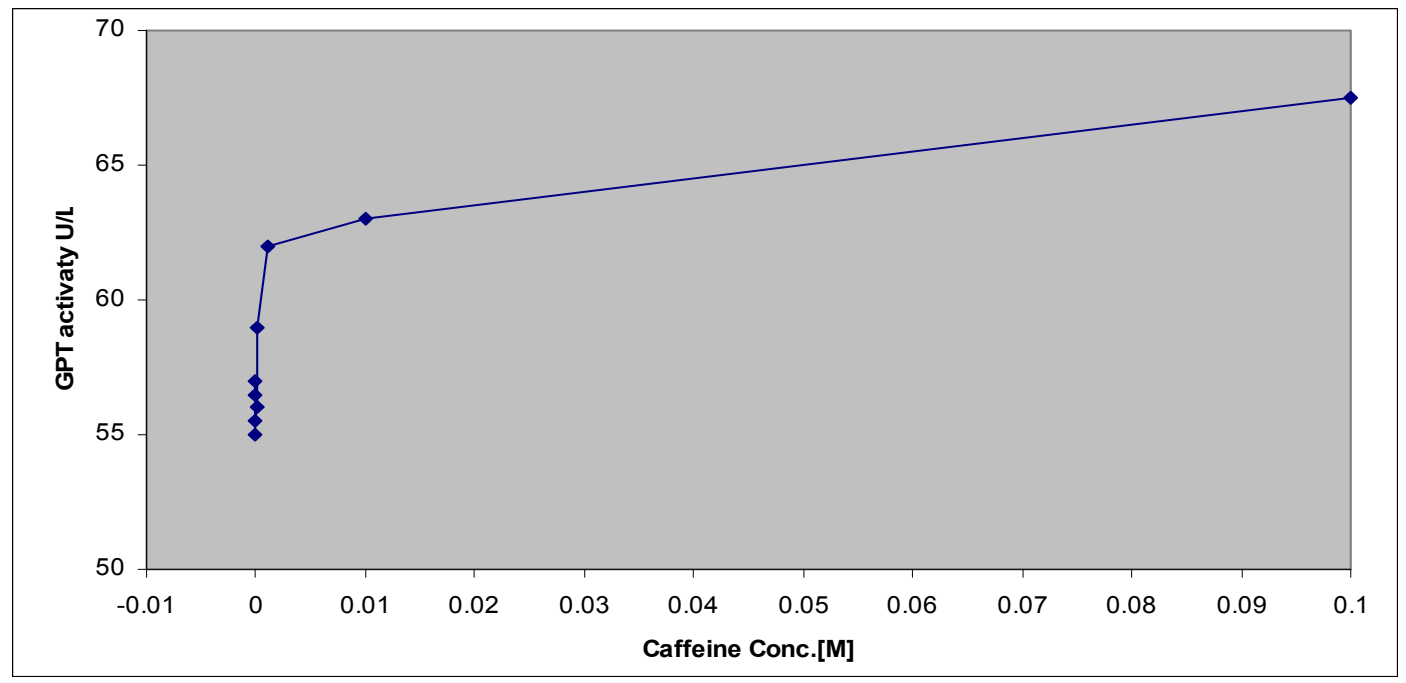

Figure 4. The relationship between concentration of caffeine and GPT enzyme activity

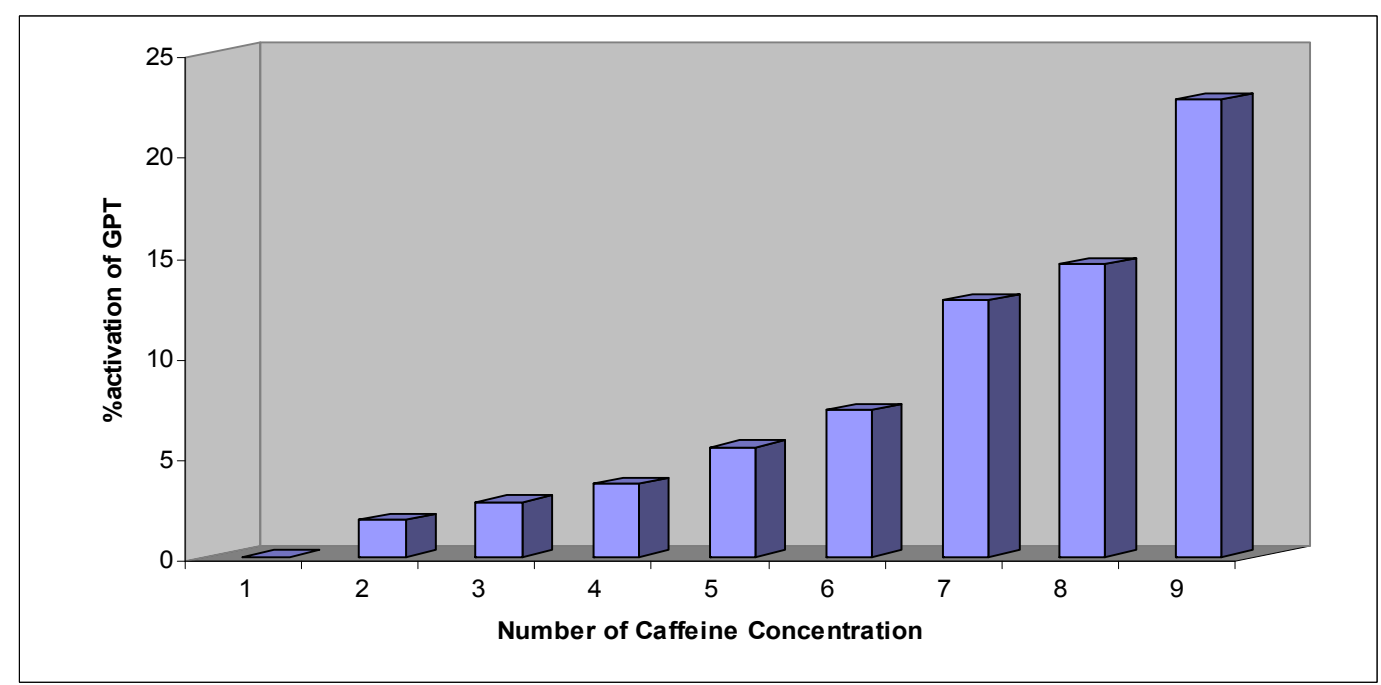

Figure 5. The percentages of activation GPT enzyme and caffeine concentration

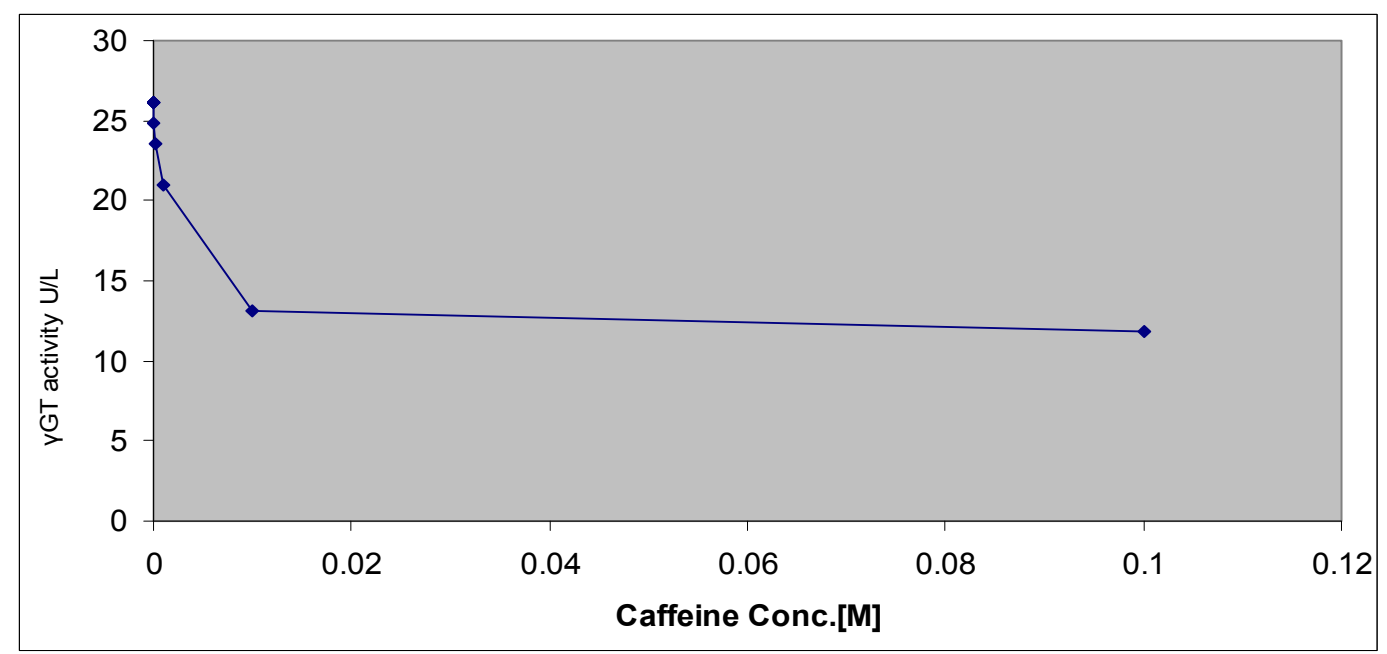

Figure 6 . The relationship between concentration of caffeine and $\gamma$-GT enzyme activity 


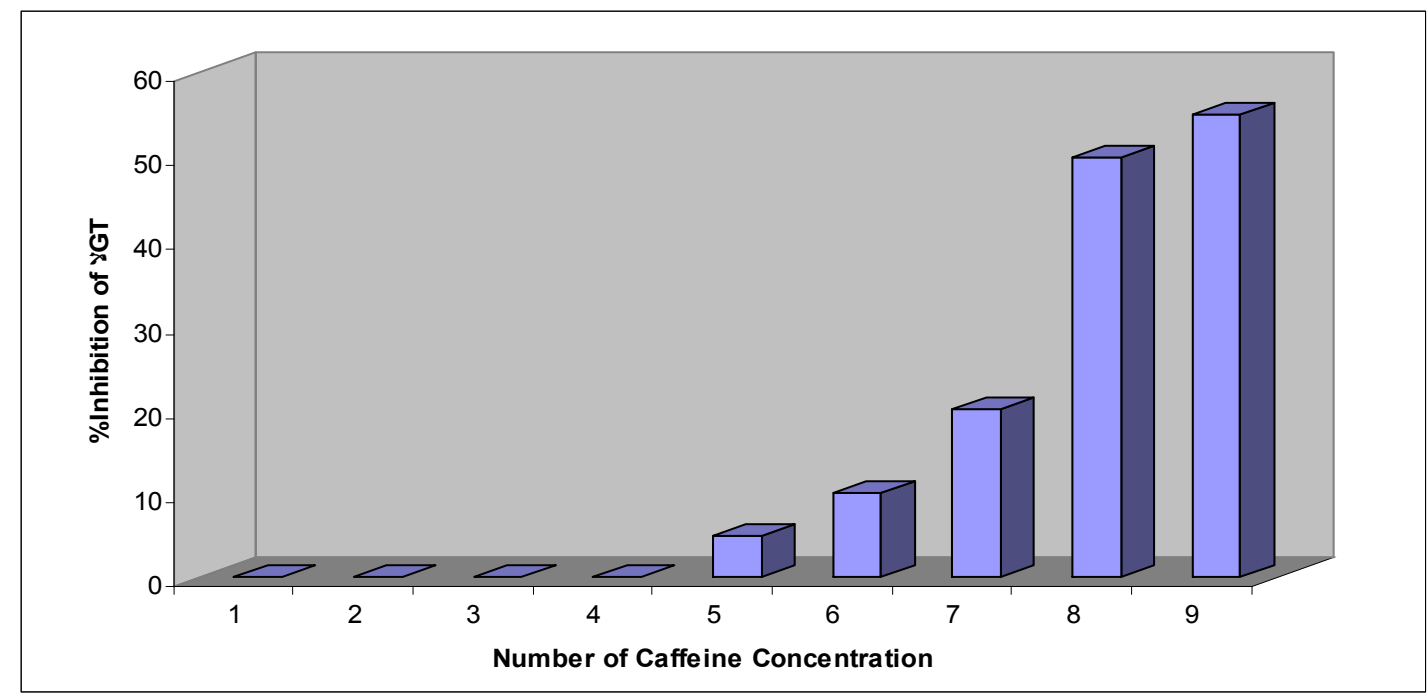

Figure 7. The percentages of inhibition $\gamma$-GT enzyme and caffeine concentration

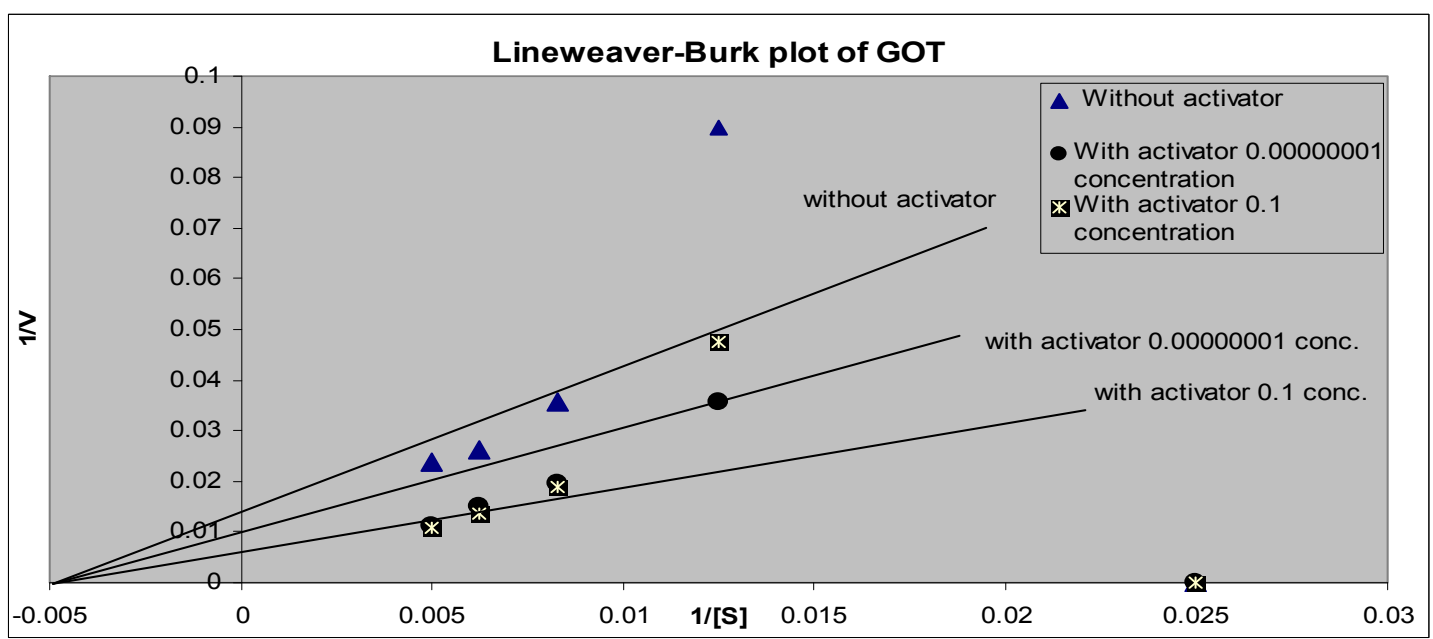

Figure 8. Lineweaver-Burk plots for caffeine effects on GOT

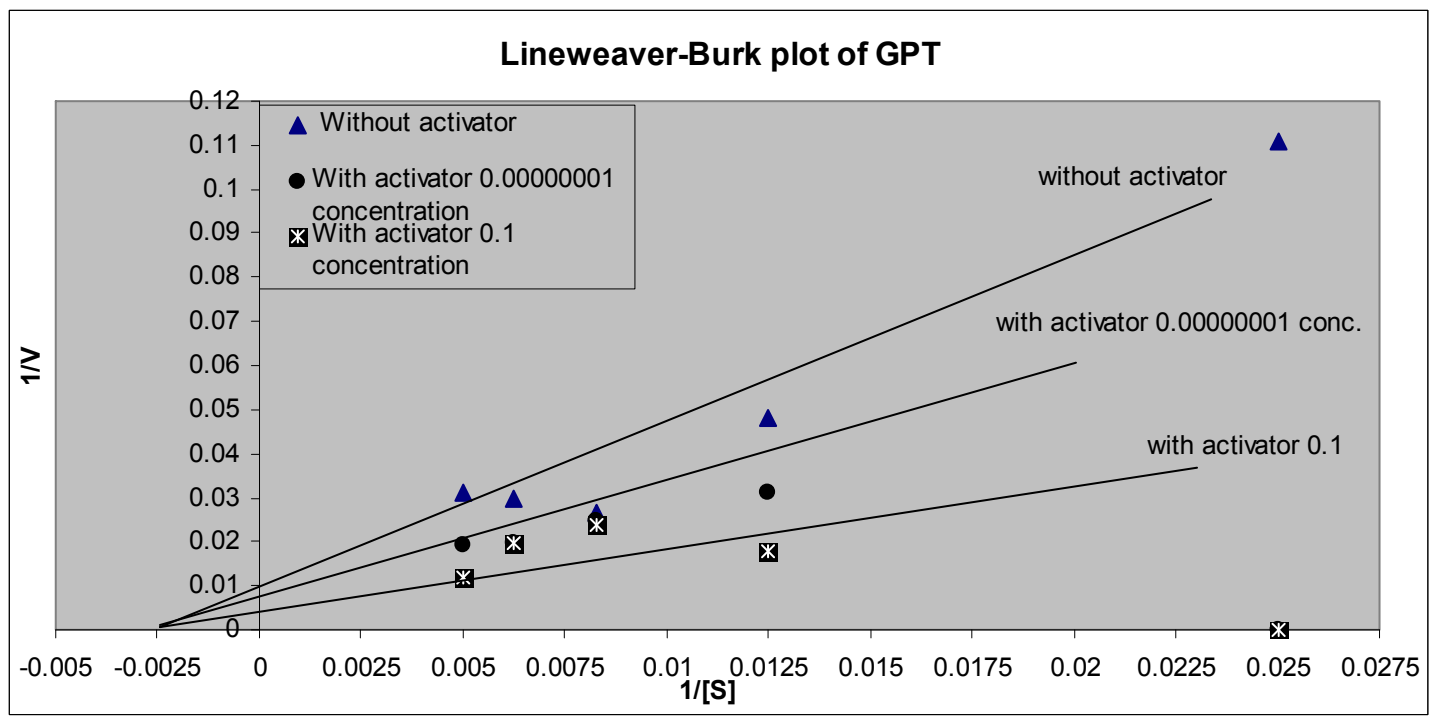

Figure 9. Lineweaver-Burk plots for caffeine effects on GPT 


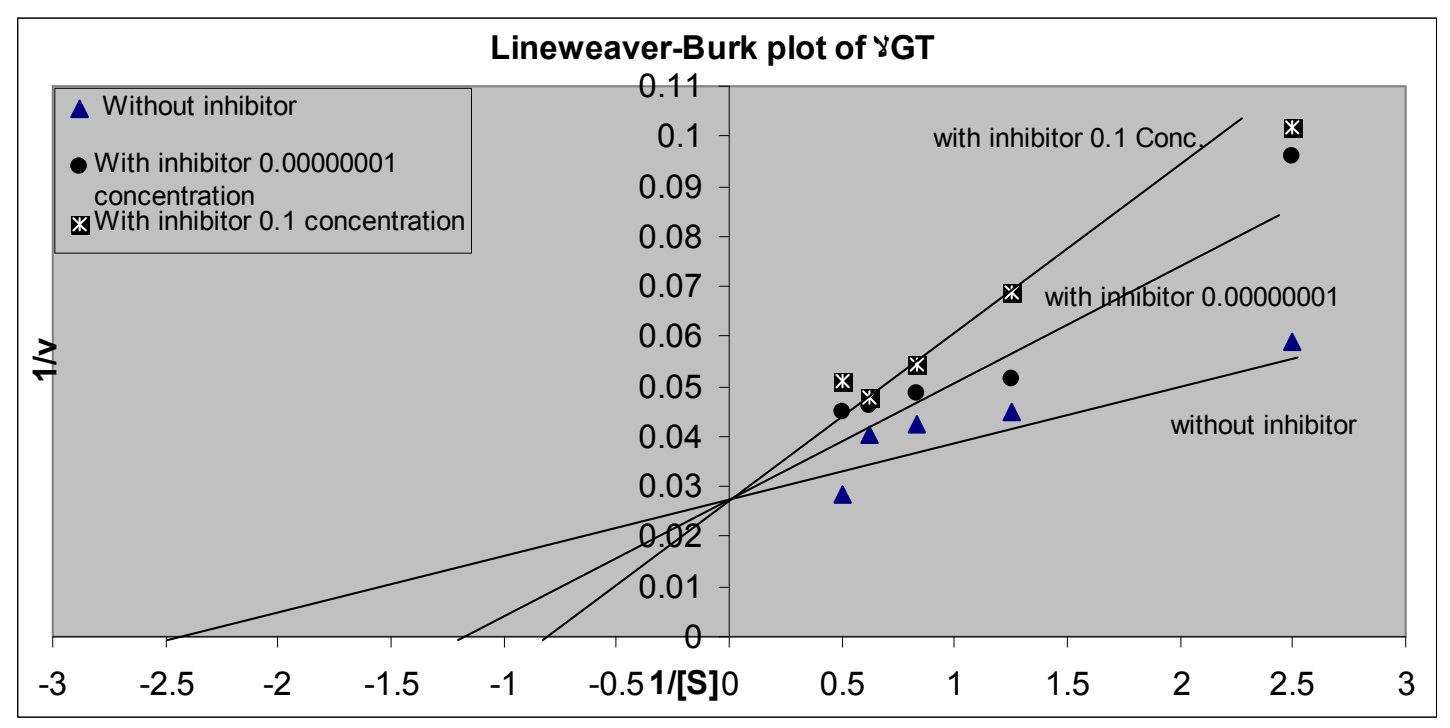

Figure 10. Lineweaver-Burk plots for caffeine effects on $\gamma$-GT 